\section{International Scientific Journal Theoretical \& Applied Science}

p-ISSN: 2308-4944 (print) ｅ-ISSN: 2409-0085 (online)

Year: $2015 \quad$ Issue: $09 \quad$ Volume: 29
Shavkat Murtazaevich Mavlanov

Researcher, Faculty of social sciences The Mirzo Ulugbek National University of Uzbekistan conference_2012@list.ru

Published: $30.09 .2015 \quad$ http://T-Science.org

SECTION 30. Philosophy.

\title{
THE REVIVAL OF SPIRITUAL VALUES IN THE CONTEXT OF TRANSFORMATION OF SOCIAL PROCESSES IN UZBEKISTAN
}

\begin{abstract}
In this article the revival of spiritual values in the modern conditions of independence development and transformation of social processes in the Republic of Uzbekistan is consider. There are some human qualities as kindness, historical truth, tolerance, family values, spirituality of people, interethnic harmony, religious values, moral values, harmonious developed youth, ecological consciousness and others are analyzed.

Key words: Uzbekistan, spiritual values, new generation, historical truth, historical memory, transformation of social processes, national values of the Uzbek people.

Language: English

Citation: Mavlanov SM (2015) THE REVIVAL OF SPIRITUAL VALUES IN THE CONTEXT OF TRANSFORMATION OF SOCIAL PROCESSES IN UZBEKISTAN. ISJ Theoretical \& Applied Science 09 (29): 24-27.
\end{abstract}

\section{Soi: http://s-o-i.org/1.1/TAS-09-29-6 Doi: crossef http://dx.doi.org/10.15863/TAS.2015.09.29.6}

In his book "High spirituality - an invincible power" the President of the Republic of Uzbekistan Islam Abduganievich Karimov noted "During the years of independence the main challenge for us was and is the education of a free citizen who knows their rights, politically literate who can engage in critical thinking, hopes only on their knowledge and capabilities, in a word comprehensively developed person" [8, p. 76.].

The last decades of the XX century and the beginning of the twenty-first century are characterized by ambiguous often painful processes in all spheres of life of the people.

The process of reform, of renewal in all areas of our life, after independence took place in a complex and ambiguous environment.

In the Republic of Uzbekistan is observed, as expressed the American political scientist Samuel Huntington, a return to the roots, or as they say in Russian literature, the revival of spiritual values of the Uzbek people. If the growth of national consciousness in the countries that are in some way depend on the West was caused by the costs of the unification process of the lifestyle in the image and likeness of West, in the former republics of the USSR, excessive centralization and acceleration of the process of cultural assimilation. The revival of spiritual values does not mean the rejection of former conquests and values. It is supposed to be more respectful of the culture, psychology and mentality of the people, but primarily the ability to show and prove to himself and the world the uniqueness and originality of its people, its originality, including in the area of spiritual and moral achievements.

Wide promotion of the best samples of national and world culture should be the basis of the spiritual education of the younger generation, the youth of today. Spiritual revival is the emergence of a new generation, a new youth, thinking which defines the spirit of independence. Spiritual revival is the emergence of a new generation of creative young people, thinking which defines the spirit of independence. The return of interest in our history, our origins, our historical memory, wide promotion of the best images of our national and world culture all this forms a new civic consciousness and is the source of spiritual education of our young people today.

About the revival of spiritual values, says the President of Uzbekistan I. Karimov: "There is leaves filled with historical events of the twentieth century. What will be the path of humanity in the twenty-first century, what will be his fate that lies ahead? What are the prospects of independent Uzbekistan, boldly invading the world community that may disturb the peace, quiet procession of the young state on the path of economic reforms?" [6, p. 5-6]. 
It must be emphasized that this problem has aroused much interest not only in the country but abroad. This is natural, because the place of Uzbekistan in the world, his policies has a huge impact on the solution of many problems not only in Central Asia but throughout the world.

No society can see their future without the development and strengthening of spiritual potential, spiritual and moral values in the minds of people.

Cultural values of the people, his spiritual heritage for millennia served as a powerful source of spirituality for the people of the East. Despite strict ideological pressure over a long period the people of Uzbekistan have managed to preserve their historical and cultural values and traditions, which are carefully passed down from generation to generation.

From the first days of our independence, the most important task, is raised to the level of state policy, was the revival of that huge, priceless spiritual and cultural heritage, which for many centuries was created by our ancestors.

The revival of spiritual values we consider as an organic, natural process of growth of national consciousness, the return to the spiritual sources of the nation, to its roots.

Since gaining political independence and freedom of our people has become a true master of his destiny, the creator of his own history, the bearer of a distinctive national culture.

However, it is necessary to emphasize that the return and restoration of the spiritual and Holy to us religious values and traditions, the knowledge of ourselves was held in difficult conditions - the conditions of the collapse of the old Imperial system and the emergence of new social relations.

After more than a century of totalitarian according to this process, at first, quite naturally took place as a kind of "negation of the negation". But we were aware that the negation of the values of the former system contains the risk of political and cultural extremism that have no constructive program. However spontaneous and unconditional return to the values, traditions and way of the past can lead to the other extreme - to the rejection of modernity, rejecting the need of modernization of society.

It was in the wake of this denial appeared the danger of extremist opposition, which, in fact, could be the opposition of spirituality. Her political aspirations is a mixture of militant nationalism, religious intolerance and hatred to the whole "not our". Our society could not be seen in a specific extremist manifestations of those days, how aggressive was this reaction, how much it destructive and hate everything that did not fit into the narrow framework of individual perception politicized militant groups.

Awareness of the danger of such developments dictate the need for a deeply thoughtful and balanced approach, design and implementation of a set of mutually reinforcing political, economic and cultural programs aimed at increasing positive, constructive nature of spiritual revival. These programs were based, primarily, on the obligation of a differentiated approach to reviving the legacy choice, first of all, the most important, ethically significant their traditions and customs, enriching human values and meet the requirements of democratization and renewal of our society.

With a special significance in the extreme conditions of that period acquired weaken and prevent emotional outbursts that could easily switch shaky line, a line from which is an ethnic conflict. This danger was ubiquitous in those days, and to this day there is convinced that only a call to mind will tolerance and humanity of our people has helped us to take this no measurable consequences of the disaster.

Essential in the process of revival and growth of national consciousness and, if you will, of national pride is the historical memory, the restoration objective and truthful history of the people of his native land, the territory of the state.

The history becomes a true educator of the nation. Acts and deeds of great ancestors evoke historical memory, form a new civic consciousness, become a source of moral education and imitation. In the history of the Central Asia there were many prominent figures, combining political intelligence and moral virtue, religious outlook and encyclopedic erudition. Our great ancestors such as Imam Bukhari, At-Termizi, Naqshband, Haji Ahmad Yassavi, alKhorezmi, Beruni, Ibn Sina, Amir Timur, Ulugbek, Babur and many others had made an enormous contribution to the development of our national culture, become truly the pride of our people. These names, their outstanding contribution to the development of world civilization known today throughout the world.

Historical experience, the continuity of traditions - all of these should be the values on which new generations are brought up. Not accidentally, our culture has become a center of attraction for all mankind: Samarkand, Bukhara, Khiva - a place of pilgrimage not only for scholars and art lovers, but for all people of the Earth who are interested in the history and historical values.

Ethnic, cultural and religious tolerance of our people is another inexhaustible source of spiritual revival. For thousands of years, the Central Asia was the center of the meeting and the coexistence of different religions, cultures and lifestyles. Ethnic tolerance and openness were the natural norms for survival and development. even those who conquered these territories, not only admired the culture of the peoples of the Central Asia, but also carefully over the tradition, the elements existed in the territory statehood. 
It was on this earth was a global enrichment of world cultures for many centuries. Here for centuries, nomadic peoples coexisted with settled, Iranian tribes with Turkic Muslims from Christians and Jews. And the last two centuries, when even States who consider themselves "civilized" and "enlightened", mired in mass pogroms and religious persecution, the land of Uzbekistan not only remained a place of peaceful unification of peoples and cultures, but also gave shelter to the representatives of persecuted peoples.

The revival of the spirit of the Uzbek people, the formation of moral ideals of the nation is a phenomenon in which deep national inextricably linked to universal. Without losing its identity, the peoples living in Uzbekistan have their common mentality, a common philosophy of conduct. Hence a single moral core that all the years of independence has been a source of inter-ethnic harmony.

The revival of the spiritual and religious foundations of society, culture of Islam that has accumulated millennial experience moral formation of our people, was an important step on the path of self-determination, gaining historical memory, cultural and historical unity. Reconstructed old mosque and built new ones; expanding the network of educational institutions; published religious literature.

Spiritual revival should apply in the relations of man to the earth and its resources. In the region where agriculture for thousands of years was based entirely on irrigated agriculture, respect for the land and water is equally important moral imperative than respect for the objects of civilization. Earth, air, water and fire (the Sun) was anciently revered in the Central Asia; they came to pay homage to all the religions of our ancestors, from Zoroastrianism to Islam.

Unfortunately, most damage over the last century was caused to the ecological system of the region was forgotten traditional environmental ethics of our ancestors, prohibiting thoughtlessly to defile and wasting water and land resources.

Especially it is necessary to emphasize the need to study and popularize the tradition of rational and harmonious use of nature in pre-Islamic culture of the peoples of the Central Asia. It is no coincidence that our earth was the birthplace of Zoroastrianism, summoning people to care about maintaining the cleanliness of rivers and soil fertility. other teachings - Buddhism and Manichaeism also preached caring and respectful attitude to nature as one of the most important ways to perfect society. Not coincidentally, these same ideas of the harmony of the relationship between Man and Nature we find in the teachings of a Central Asian Sufism, made a huge contribution to the Muslim Renaissance in the Movarounnahr.

Another powerful source of spiritual values is the traditional ethics of the family and kinship relations, the basic principles which have always had respect for elders, mutual aid, care for children. Unfortunately, these values have been severely deformed in the Soviet period. Banning private enterprise, suppressing, under the pretext of "nepotism", the continuity of professional skills in families and genera, the Soviet regime contributed to the loss of the families and genera of their traditional professional and economic "niches". As a result, these skills and moral standards, having been blocked, began to take socio ugly cronyism and nepotism. When they do this kin mutual aid was sometimes result in dependency and protectionism hindering the development of society.

The revival of family values and kinship should mean not perpetuating tribal relations, but the possibility of economic, cultural and professional emancipation of each family.

The revival of spiritual values means also their adaptation to the values of the modern world and the information civilization.

Positive values brought about by modern civilization, we refer to the values associated with the process of building a legal democratic society. It is the respect for human rights, freedom of enterprise, freedom of speech, freedom of the press, etc.

Human in man is formed not mechanical consumption of cultural values and spirituality contained in them. In life you often meet people educated, with broad knowledge, learned well the different requirements of society, but at the same time being extortionists, selfish, i.e. spiritually poor. Therefore, spirituality is not foreign "culture," and internalized the content of culture, evolving into an inner conviction, world outlook, initial demand, the positive qualities of the person.

\section{References:}

1. (2000) Ideja nacional'noj nezavisimosti: osnovnye ponjatija i principy. - T.: Uzbekistan.

2. Karimov IA (1999) Bez istoricheskoj pamjati net budushhego. Sobr. Soch. T. 7. -T.: Uzbekistan, 1999.
3. Karimov IA (2005) Nasha glavnaja cel' demokratizacija i obnovlenie obshhestva, reformirovanie i modernizacija strany. T.: Uzbekistan, 2005. 


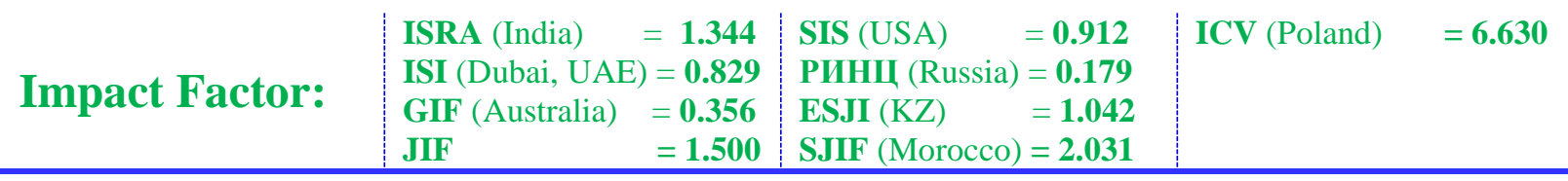

4. Karimov IA (2000) Nasha vysshaja cel' nezavisimost' i procvetanie Rodiny, svoboda i blagopoluchie naroda. -T.: Uzbekistan, 2000.

5. Karimov IA (2006) Obespechenie interesov cheloveka, sovershenstvovanie social'noj zashhity - nasha prioritetnaja zadacha. T.: Uzbekistan, 2006.

6. Karimov IA (1997) Uzbekistan na poroge XXI veka: ugrozy bezopasnosti, uslovija i garantii progressa. -T.: Uzbekistan, 1997.

7. Karimov IA (2011) Uzbekistan na poroge dostizhenija nezavisimosti. T.: Uzbekistan, 2011.
8. Karimov IA (2008) «Juksak ma\#navijat engilmas kuch». T.: 2008.

9. (2013) Konstitucija Respubliki Uzbekistan. -T.: 2013.

10. Mandral'skaja NV (1997) Uzbekistan v XX veke: istoricheskij vzgljad na problemu nacional'noj gosudarstvennosti cherez prizmu nacional'nogo - internacional'nogo obshhechelovecheskogo (1917-1991 gg.). - T.: TUIT, 1997. 